\title{
Design of "Parallel" Model of Character Education in Families Based on Character Education in Schools
}

\author{
Syuraini ${ }^{1, *}$, Ilpi Zukdi ${ }^{2}$ \\ ${ }^{l}$ Department of Non Formal Education, Faculty of Education, Universitas Negeri Padang, Padang, Indonesia \\ ${ }^{2}$ Department of Islamic Education, Faculty of Tarbiyah and Teacher Training, Universitas Islam Negeri Imam Bonjol, \\ Padang, Indonesia \\ *Corresponding author. Email: syuraini@.fip.unp.ac.id
}

\begin{abstract}
This study aims to determine the picture of character education models implemented by teachers in PAUD. The research method uses R\&D with the ADDIE development model. The study population was all kindergarten teachers in Aisyiyah, Padang, who came from 30 kindergartens. Samples were taken using a multi-stage random sampling technique with categories of downtown, suburbs, and between downtown and suburbs. The results of this first year research show a tendency for teachers to instill religious values, independence, and help to be done with habituation. To instill the values of honesty and tolerance teachers are more likely to use examples, while instilling the values of discipline and responsibility using rules. The following year this study will design a "Parallel" model of character education that can be carried out by teachers and parents of early childhood simultaneously. It is recommended to the teacher to always communicate with parents in shaping the character of early childhood so that parents can do the same thing with what teachers do at school.
\end{abstract}

Keywords: "Parallel", character education, school, family

\section{INTRODUCTION}

Today there is a lot of moral degradation and character values are not well embedded. The rise of free sex among adolescents, drug trafficking, student brawls, pornography, crime, and massive corruption[1]. Death of a teacher in Sampang Madura after being persecuted by his students (Kedaulatan Rakyat, 3 February 2018). Corruption with members of Malang City DPRD (Republika, 3 September 2018). Sexual abuse of elementary school children (Kompas.com, February 22, 2019). The latest development that is very sad is the marriage of fellow siblings (inces). This makes the face of the parents turn red to bear the shame of having failed to educate children. Some of these cases reflect the lack of parental supervision, the superficial instillation of character values by parents, especially religious values that can shape a child into faith and piety.

The main purpose of education is to form people of faith and devotion to Allah Azza wajalla and noble character. Faith and piety have a very essential and fundamental meaning in life. With faith someone believes and believes in the greatness and love of God towards his servant. With faith a person becomes a tough and tenacious person in life. With faith someone becomes a person who always acts according to the norms adopted and ultimately has high self-discipline. In short the power of faith can defeat the bad and establish the right. The Word of God in Surah Al Hujurat verses 7-8 states:
"Allah makes you "love" to faith and makes faith beautiful in your heart and makes you hate disbelief, ungodliness, and iniquity. These are the people who follow the right path, as gifts and favors from Allah. And Allah is Allknowing, All-Wise.".

If someone already has faith and piety then he will do good deeds. Good deeds will emanate from radiant faces and noble deeds. Goodness for the good that is embedded in a person will be collected into a value that has. That is what characterizes a person's personality and that's also the character he has.

In everyday life it is expected that every child has good character values because a child who has good character means that he has acted in accordance with religious norms and this also means that the child has taken the straight path (shirathal mustaqiim). The desired life is a life that follows a straight path, not a false one [2]. In connection with a righteous and righteous life, God commands his people to ask for directions to be given a straight path (ihdinasshiraathal mustaqiim). In a straight path man is given infinite favor.

The creation of children who have good character requires integrative holistic handling both methodologically, subjectively, and practically. Methodologically it is necessary to have an educational method that can foster the values of goodness, truth, and noble character. Subjectively requiring intensive handling in every line of life of the child where he is, whether in the family (parents and family members), at school (principals, teachers, employees, and peers), and in the community. Syarbini[3] stated the role of teachers and parents is very important in 
fostering the character of children in various ways. Research result of Muntaha \& Wekke[4] found that parents want their children not only to work, but also to have a good attitude and are active at work. With good attitude at work, children become people who are responsible for their work. Practically, there is a need for continuous collaboration between the environment in which it is located. An environment that can shape the character of children, families, schools and communities. This collaboration must be carried out and designed by the school with its partners, namely parents, community leaders, the business world, the industrial world and other partners in groups and individually. This is in line with the results of the study of Widodo[5], in the context of the revitalization of learning, education and teaching must be carried out with a system approach that prioritizes harmony, cohesiveness and holiness reflected in the attitudes and actions of various school activities.

\section{METHOD}

This research was designed in the form of research and development. The development procedure uses the ADDIE model (Analyze, Design, Develop, Implement, and
Evaluate) (Branch in Widyaningsih \& Budiningsih 2016). The population of this research is all Kindergarten 'Aisyiyah Kindergarten school teachers in the city of Padang originating from 30 kindergartens spread across all districts in the city of Padang with a total of 210 teachers. The research sample was taken using multi-stage random sampling with categories of downtown, suburbs, and between downtown and suburbs. Each cluster is taken one kindergarten. Thus the number of teachers sampled came from three schools. Data collection was carried out using a questionnaire technique that was analyzed using the percentage formula

\section{RESEARCH RESULT}

Based on data collected through a questionnaire about character education carried out by teachers in schools viewed from religious values, honesty, discipline, tolerance, please help, and responsibility are illustrated there are several ways that teachers do in instilling character values. The more dominant way is done by habituation, then followed by exemplary and giving rules. For more details can be seen in table 1 .

Table 1 Overview of How Teachers in Schools Embed Character Value in Early Childhood

\begin{tabular}{|c|c|c|c|c|c|}
\hline \multirow[t]{3}{*}{ No. } & \multirow{3}{*}{$\begin{array}{l}\text { Value of } \\
\text { Embedded } \\
\text { Character }\end{array}$} & \multicolumn{4}{|c|}{ The method used } \\
\hline & & $\begin{array}{l}\text { Exampl } \\
\mathrm{e}\end{array}$ & $\begin{array}{l}\text { Comman } \\
\text { ds }\end{array}$ & $\begin{array}{l}\text { Habituati } \\
\text { on }\end{array}$ & Rules \\
\hline & & $\%$ & $\%$ & $\%$ & $\%$ \\
\hline 1. & Religious & 14,27 & 3.33 & 74,76 & 7,14 \\
\hline 2. & Honesty & 61,49 & 20,69 & 10,34 & 7,47 \\
\hline 3. & Discipline & 14,43 & 3,98 & 29,85 & 51,74 \\
\hline 4. & Tolerance & 53,71 & 0,93 & 41,66 & 3,70 \\
\hline 5. & Mandiri & 42,99 & 3,91 & 50,16 & 2,94 \\
\hline 6. & Mutual help & 42,86 & 3,04 & 52,04 & 3,06 \\
\hline 7. & Responsible & 5,23 & 11,94 & 35,82 & 47,01 \\
\hline & Average $\%$ & 33,54 & 6,83 & 42,06 & 17,57 \\
\hline
\end{tabular}

From table 1 it can be seen that the teacher carries out character education to children in a variety of ways, but the dominant way is done with habituation $(42.06 \%)$ followed by an example of $33.54 \%$. For more details can be seen in Figure 1.

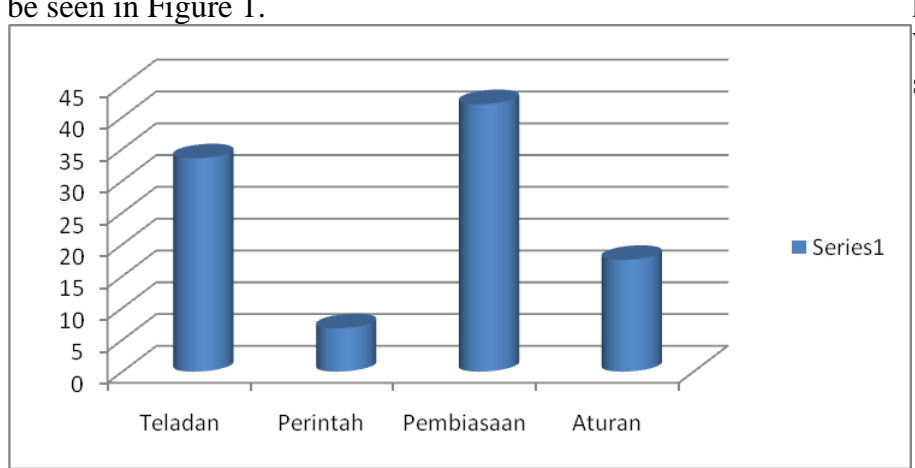

Figure 1 Histogram Overview of How Teachers in Schools Embed Character Values in Early Childhood
Seen from Figure 1 it is very clear that the inculcation of character values by teachers to early childhood is done by habituation and role models. It also means that the best way to instill character values in children is to make it a habit and set a good example for children.

When viewed from the model framework found, it can be seen in Figure 2 below: 


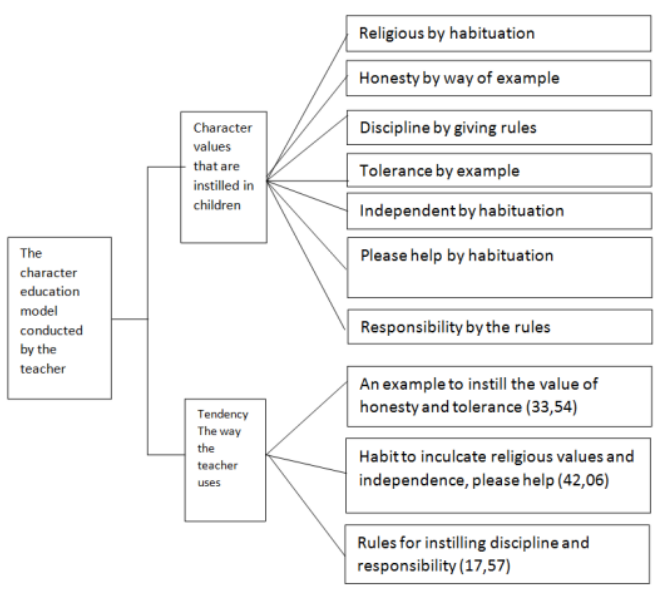

Figure 2 Character Education Model in schools

The character education model that teachers do in schools as shown in Figure 2 must be communicated and collaborated with parents. Thus a parallel model can be raised for the inculcation of character values in early childhood. Based on Figures 1 and 2, the following will illustrate the design of a character education model that is made in accordance with the results of the study.

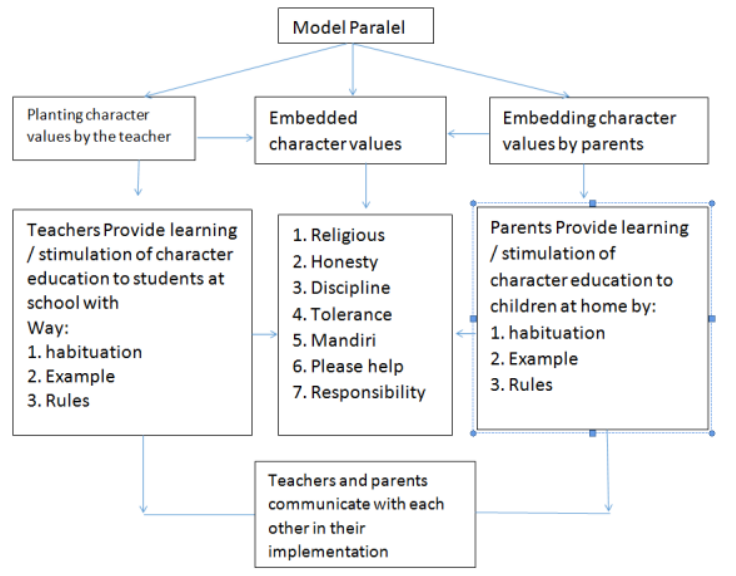

Figure 3 Model "Parallel" Cultivation of Character Values in Family Based on Character Education in Schools

\section{DISCUSSION}

The results showed that the character education carried out by teachers in schools was not much different from that carried out by parents at home. The teacher also makes habituation of the child but for many things the teacher shapes the character of the child by example and by providing rules especially in forming discipline to the child. The methods used by teachers are more diverse because many things are needed in shaping the character of children. This is very possible because teachers have high authority especially for early childhood. Kesuma (2012) concluded that the absolute requirement in character education is the authority of the teacher.
Character education will not be realized when the teacher is assumed to not be authoritative in the eyes of the students and authority becomes very important in instilling values in children. With authority / gezah the teacher is what makes students comply with all the rules made. This will be even more possible when the teacher collaborates and together with parents makes and applies all the necessary rules in shaping student character [8].

When observed in the learning process of children in PAUD it turns out that teachers often become idols by students so that what the teacher says is true in the child's view. The teacher is everything to the child, the teacher is the most beautiful, the smartest most adhered to by young children. This condition is a big potential in early childhood education in educational institutions. Therefore teachers must be prepared in all conditions to be role models for children. If the teacher is wrong in behaving and behaving, it will be fatal to the formation of the child's next character [9].

The way the teacher instills character values to children by example is very appropriate with the teachings of Islam where the prophet Muhammad was sent to the earth is to be emulated. The Word of God in Surah Al-Ahzab verse 21 "Indeed, there is already in the Prophet's self a good role model". This also has the meaning that the example becomes the main in educating children and all the behavior of teachers and parents will be imitated by children.

According to Ulwan[10] educators (teachers and parents) are the best figures in the child's view. Acts, manners and all his actions are realized or will not be imitated by the child (students), words, actions and actions will always be embedded in the child's personality. This is in line with what was conveyed by Muslich[11] that the methods used in the learning process related to the inculcation of character values include, for example, and role playing both playing a macro role and playing a micro role. By playing the role, the child (student) plays what he has seen and heard from the environment in which the child is.

Habituation is also a method that is often used by teachers to instill character values in children, especially to instill religious values, independence, and help. According to Syarbini[12]; Rianawati[10] habits that children do from an early age will be a hobby and identity for children to adulthood. Teachers who make habituation to children will see a change in attitude in children. Children will behave in accordance with what the teacher accustomed to so that the behavior of children who during this time there may be less good will change for the better. This is consistent with the results of research conducted by Rusmayanti[13] that habituation can reduce or change wrong or unfavorable behavior in children.

Habituation also makes children disciplined in carrying out daily activities. Research Ihsani, Kurniah, \& Suprapto[14] have found good results in the application of habituation that makes children already disciplined in coming to school, returning toys in their place and using objects according to their function. It's just that sometimes teachers are still less consistent in their implementation. In connection with the results of this study, it is of course 
expected that parents at home do the same thing or together with what teachers do at school. Parents also have to get used to good behavior for children such as when to eat, when to play, get used to pray before and after eating, rearrange toys, put shoes in place and other activities that require habituation.

If the teacher has carried out character education well what about parents at home? Actually, parents must have the authority as expressed by Rifai[15] that education in the family must run in association between family members and parents characterized by the existence of parental authority and a sense of friendship between parent and child. The approach used is a humanitarian approach characterized by a sense of responsibility and affection. The next question is whether parents have also become an idol for their children? Has the teacher told parents what has been done? Has the teacher informed parents what parents must do at home so that it is compatible in their actions? Ironically, teachers have difficulty inviting parents to work together in dealing with students' problems, because parents often assume that education is not their responsibility but the teacher's responsibility. Therefore, researchers will create a model of cooperation between teachers and parents in instilling character values in children. Agboola in Indah, Sari, Sudigdo, \& Amalia[16] states that education policy must take the initiative to actualize character education in the school system. Done together, parents, teachers and administrators as stakeholders must join together to encourage students to realize good values in their lives. With the harmony of educating between teachers at school and parents at home, it is hoped that the planting of character values will bear fruit.

\section{CONCLUSION}

The results and discussion of the research that have been presented in the previous section illustrate that character education carried out by teachers in schools has a variety of ways in accordance with the character values that are instilled and developed. The character value developed determines the way the teacher must do. Thus, it can be said that the teacher has carried out the inculcation of character values to the child beyond the way parents do at home ie by traditionally imitating what the parents did before. Therefore, teachers must be able to innovate learning by creating activities that can involve parents and the community so that they can better deal with the problem of character planting.

\section{REFERENCES}

[1] D. Kesuma, C. Triatna, and J. Permana, Pendidikan Karakter Kajian Teori dan Praktik di Sekolah. Bandung: PT Remaja Rosdakarya, 2011.

[2] Ardimen, "Bimbingan dan Konseling Komprehensif Berbasis Karakter Cerdas dan Aplikasinya
Melalui Bimbingan Teman Sebaya di Era Globalisasi," Edukasia J. Penelit. Pendidik. Islam, vol. 12, no. 2, pp. 483-508, 2017.

[3] Rosikum, "Peran Keluarga dalam Implementasi Pendidikan Karakter Religius Anak Rosikum," $J$. Kependidikan, vol. 6, no. 2, pp. 293-308, 2018.

[4] P. Z. Muntaha and I. S. Wekke, "Pendidikan Akhlak Remaja bagi Keluarga Kelas Menengah Perkotaan," Cendekia, vol. 15, no. 2, pp. 242-263, 2017.

[5] W. Widodo, "Peranan Organisasi Pembelajaran dalam Mengoptimalkan Inovasi Guru," Ter. J. Bimbing. dan Konseling, vol. 1, no. 3, pp. 220-224, 2018.

[6] Widyaningsih and T. E. Budiningsih, "Perbedaan Academic Self Efficacy Ditinjau dari Jenis Goal Orientation," INTUISI J. Ilm. Psikol., vol. 8, no. 2, pp. 27, 2016.

[7] D. Kesuma, Pendidikan Karakter Kajian Teori dan Praktik di Sekolah. Bandung: PT Remaja Rosdakarya, 2012.

[8] G. W. Qomaro, "Pengaruh Keteladanan dan Kewibawan Guru Terhadap Sikap Tawadhu’ Siswa di MTS dan MA Sunan Drajat-Geger-Bojonegoro Tahun Pelajran 2015," Didakt. Relig., vol. 4, no. 1, pp. 55-75, 2016.

[9] I. B. Maryatun, "Peran Pendidik PAUD dalam Membangun Karakter Anak," J. Pendidik. Anak, vol. 5, no. 1, pp. 747-752, 2016.

[10] S. Manan, "Pembinaan Akhlak Mulia melalui Keteladanan dan Pembiasaan," J. Pendidik. Agama Islam Ta'lim, vol. 15, no. 1, pp. 49-65, 2017.

[11] M. Muslich, Pendidikan Karakter: Menjawab Tantangan Krisis Multidimensional. Jakarta: Bumi Aksara, 2011.

[12] Yunani, "Model Pendidikan Karakter dalam Keluarga (Studi Kasus pada Keluarga yang Istrinya Berprofesi sebagai Guru PAI SD di Lingkungan UPTD Pendidikan Kecamatan Jalaksana Kabupaten Kuningan," OASIS (Jurnal Ilm. Kaji. Islam., vol. 2, no. 1, pp. 1-19, 2017.

[13] E. Setiawati, Desri, and E. Solihatulmilah, "Permainan Ular Tangga dalam Mengingkatkan Kemampuan Moral Anak," J. PETIK, vol. 5, no. 1, pp. 8591, 2019

[14] N. Ihsani, N. Kurniah, and A. Suprapto, "Hubungan Metode Pembiasaan dalam Pembelajaran dengan Disiplin Anak Usia Dini," J. Ilm. Potensia, vol. 3, no. 1, pp. 50-55, 2018.

[15] M. S. S. Rifai, Ilmu dan Aplikasi Pendidikan. Bandung: Pedagogiana Press, 2009. 
[16] D. Indah, P. Sari, A. Sudigdo, and R. D. Amalia, "Pembelajaran Tari Kreasi Anak Tuna Grahita Ringan Melalui Proses Imitatif," Trihayu J. Pendidik. Ke-SD-an, vol. 4, no. 2, pp. 302-313, 2018. 